\title{
Psoriasis and Psychiatry: An Update
}

\author{
Madhulika A. Gupta, M.D., FRCP(C)*
}

Psychodermatology Clinic, Department of Psychiatry, Toronto Western Hospital, University of Toronto, Toronto, Ontario, Canada

Aditya K. Gupta, M.A., M.D.

Department of Dermatology, University of Michigan, Ann Arbor, Michigan

\section{Herbert F. Haberman, M.D., FRCP(C)}

Division of Dermatology, Department of Medicine, Toronto Western Hospital, University of Toronto, Toronto, Ontario, Canada

\begin{abstract}
Psychosocial factors are important in the onset and or exacerbation of psoriasis in $40 \%-80 \%$ of cases. Yet psoriasis has received little attention in the recent psychiatric literature. A subgroup of psoriatics appear to be "stress reactors" and these patients may have a better long-term prognosis. Identification of such patients early in the course of treatment and incorporation of specific psychosocial interventions in their overall treatment regimen may improve the course of illness. Psoriasis has also been associated with suicide and an increased prevalence of alcoholism. The disturbances in body image perception and the effect of psoriasis on interpersonal, social, and occupational functioning can further contribute to the overall morbidity, especially if psoriasis first occurs during a developmentally critical period like adolescence. Certain biochemical and physiologic correlates of psoriasis of interest to the psychiatrist such as exacerbation of psoriasis with lithium therapy and increased cutaneous blood flow are discussed. Finally, some practical guidelines are provided for psychosocial interventions in psoriasis.
\end{abstract}

Psoriasis is a chronic cutaneous condition with a $1 \%-2 \%$ prevalence in the general population [1]. Both genetic and environmental factors are believed to play an important role in the pathogenesis of this disorder [1]. Psoriasis is associated with an increased rate of proliferation of the epidermal cells; the characteristic lesions are deep red, thickly scaling plaques that may affect any region of the

*Currently also with the Department of Psychiatry, University of Michigan, Ann Arbor, MI. skin. Psychosocial factors have been implicated by some as being important in the onset and/or exacerbation of psoriasis in $40 \%$ [2-5] to $80 \%[6,7]$ of cases. Furthermore, psoriasis has been associated with suicide [8], and an increased prevalence of alcoholism in comparison with other chronic dermatologic disorders [9], and a range of personality characteristics (Table 1) [3-7, 10-18]. In the dermatologic literature, psoriasis has been classified as a disorder where emotional and constitutional factors "collaborate in different degrees" [20]. In the psychiatric literature, psoriasis is listed under psychosomatic disorders, or a disorder where psychologic factors affect the physical condition [21]. However, in spite of the fact that psoriasis may be significantly affected by psychosocial factors and be associated with potentially serious and life-threatening psychopathology, it has received very little attention in the recent psychiatric literature. Knowledge of the psychiatric and psychosocial concomitants of psoriasis is not only important for the consultation-liaison psychiatrist, but also for general psychiatrists, who will most likely encounter patients with this common disorder in their practice.

This paper critically evaluates the literature on the psychosocial aspects of psoriasis and reviews it under the following four major headings: 1) role of psychosocial "stress" in the onset or exacerbation of psoriasis, 2) association of psoriasis and psy- 
Table 1. Literature on the psychosocial aspects of psoriasis

\begin{tabular}{|c|c|c|c|c|c|}
\hline $\begin{array}{l}\text { Author(s) } \\
\text { Year of } \\
\text { Publication }\end{array}$ & $N$ & $\begin{array}{c}\text { Nature of Psoriatic } \\
\text { Subjects }\end{array}$ & Nature of Controls & $\begin{array}{l}\text { Psychosocial } \\
\text { Measures }\end{array}$ & Result \\
\hline $\begin{array}{l}\text { Wittkower [3] } \\
\quad 1946\end{array}$ & 86 & Military patients & No controls & Clinical interviews & $\begin{array}{l}\text { a) No one personality } \\
\text { type in psoriasis } \\
\text { b) In } 40 \% \text { cases, } \\
\text { emotional factors } \\
\text { believed to be im- } \\
\text { portant basis for } \\
\text { psoriasis } \\
\text { c) } 16 \% \text { were "psy- } \\
\text { chiatrically ill" } \\
\text { with a range of di- } \\
\text { agnoses, e.g., hys- } \\
\text { teria; reactive } \\
\text { depression, psy- } \\
\text { chopathic } \\
\text { personality. }\end{array}$ \\
\hline $\begin{array}{l}\text { Susskind et } \\
\text { al. [4] } 1959\end{array}$ & 20 & Inpatients & No controls & $\begin{array}{l}\text { Maudsley Medical } \\
\text { Questionnaire } \\
\text { (MMQ) }\end{array}$ & $\begin{array}{l}\text { a) MMQ scores not } \\
\text { significantly } \\
\text { elevated } \\
\text { b) In } 40 \% \text { cases psy- } \\
\text { chologic factors as- } \\
\text { sociated with } \\
\text { onset of psoriasis, } \\
\text { in } 70 \% \text { cases, they } \\
\text { were associated } \\
\text { with relapse. }\end{array}$ \\
\hline
\end{tabular}

$\begin{array}{ccc}\begin{array}{c}\text { Goldsmith et } \\ \text { al. [10] } 1969\end{array} & \text { Inpatients } & \text { Heterogenous } \\ & & \text { group of 13 der- } \\ & & \text { matologic } \\ & & \text { inpatients }\end{array}$

a) Minnesota Multiphasic Personality Inventory (MMPI)

b) Maudsley Personality Inventory (MPI) a) Increased scores in psychasthenia and hysteria subscales MMPI

b) No significant difference between MPI scores

a) "Modest but significant" correlation between stress and severity of psoriasis at 0.28

b) Personality profile scores within normal range.

a) $38 \%$ inpatients reported flare ups "always" associated with "worry" $42 \%$ reported flare ups "sometimes" associated with "worry" $26 \%$ con(continued) 


\begin{tabular}{|c|c|c|c|c|c|}
\hline $\begin{array}{l}\text { Author(s) } \\
\text { Year of } \\
\text { Publication }\end{array}$ & $N$ & $\begin{array}{c}\text { Nature of Psoriatic } \\
\text { Subjects }\end{array}$ & Nature of Controls & $\begin{array}{c}\text { Psychosocial } \\
\text { Measures }\end{array}$ & Result \\
\hline & & & & $\begin{array}{c}(\overline{\mathrm{CPI}}) \\
\text { c) } \mathrm{MMPI}\end{array}$ & $\begin{array}{l}\text { sumed "tranquil- } \\
\text { izer" to control } \\
\text { psoriasis } 20 \% \text { con- } \\
\text { sumed "moderate } \\
\text { to heavy" amounts } \\
\text { of alcohol } \\
\text { b) No significant ab- } \\
\text { normalities on the } \\
\text { CPI and MMPI. }\end{array}$ \\
\hline $\begin{array}{l}\text { Jobling [12] } \\
1976\end{array}$ & 180 & $\begin{array}{l}\text { Members of the } \\
\text { Psoriasis Associ- } \\
\text { ation of the } \\
\text { United Kingdom }\end{array}$ & No controls & $\begin{array}{l}\text { Author's own self- } \\
\text { rating } \\
\text { questionnaire }\end{array}$ & $\begin{array}{l}84 \% \text { reported "worst } \\
\text { thing" about hav- } \\
\text { ing psoriasis was } \\
\text { difficulty encoun- } \\
\text { tered in establish- } \\
\text { ing social contacts } \\
\text { and embarassment } \\
\text { about appearance. }\end{array}$ \\
\hline
\end{tabular}

\begin{tabular}{|c|c|c|c|c|c|}
\hline $\begin{array}{l}\text { Van der } \\
\text { Schaar [13] } \\
\text { 1976/77 }\end{array}$ & 48 & Outpatients & $\begin{array}{l}\text { "Psychosomatic pa- } \\
\text { tients" with } \\
\text { asthma, coronary } \\
\text { artery disease, } \\
\text { dysmenorrhea } \\
\text { and vasomotor } \\
\text { rhinitis }\end{array}$ & $\begin{array}{l}\text { a) Amsterdam Bio- } \\
\text { graphic Question- } \\
\text { naire (Wilde, 1963) } \\
\text { b) Social Anxiety } \\
\text { Scale (Willens et } \\
\text { al, 1973) }\end{array}$ & $\begin{array}{l}\text { a) No difference be- } \\
\text { tween psoriatics } \\
\text { and controls in } \\
\text { neuroticism, ex- } \\
\text { troversion and } \\
\text { self-defensive } \\
\text { scores } \\
\text { b) In both sexes so- } \\
\text { cial anxiety scores } \\
\text { did not differ from } \\
\text { normals. }\end{array}$ \\
\hline
\end{tabular}

\begin{tabular}{|c|c|c|c|c|}
\hline $\begin{array}{l}\text { Seville [5] } \\
\quad 1977\end{array}$ & 132 & $\begin{array}{l}\text { Patients whose } \\
\text { psoriasis had re- } \\
\text { sponded well to } \\
\text { treatment fol- } \\
\text { lowed up for } 3 \\
\text { years }\end{array}$ & $\begin{array}{l}130 \text { patients with } \\
\text { upper respiratory } \\
\text { infections and be- } \\
\text { nign or malignant } \\
\text { skin tumors }\end{array}$ & $\begin{array}{l}\text { Patients asked if they } \\
\text { had experienced a } \\
\text { major upset or ill- } \\
\text { ness just before } \\
\text { onset of rash }\end{array}$ \\
\hline
\end{tabular}

a) $39 \%$ psoriatics versus $10 \%$ controls recalled "specific stress" 1 month before onset of symptoms

b) Relapse rate was lower when rash followed "stress."

\begin{tabular}{|c|c|c|c|c|}
\hline $\begin{array}{l}\text { Roenigk et al. } \\
\text { [14] } 1978\end{array}$ & 84 & $\begin{array}{l}\text { Inpatients and } \\
\text { outpatients }\end{array}$ & No controls & $\begin{array}{l}\text { Authors' own self- } \\
\text { rating scale }\end{array}$ \\
\hline
\end{tabular}

a) Psychosocial life of females more affected than males

b) Authors attribute above to "females being more conscious of their appearance than males."

$\begin{array}{lll}\begin{array}{c}\text { Shanon [15] } \\ 1979\end{array} \quad 100 & \begin{array}{c}\text { Patients who had } \\ \text { been incarcer- } \\ \text { ated during war }\end{array}\end{array}$ No controls
a) Thorough life history
$72 \%$ cases psoriasis "stressogenic"




\begin{tabular}{|c|c|c|c|c|}
\hline $\begin{array}{c}\text { Author(s) } \\
\text { Year of } \\
\text { Publication }\end{array}$ & $N$ & $\begin{array}{c}\text { Nature of Psoriatic } \\
\text { Subjects }\end{array}$ & Nature of Controls & $\begin{array}{c}\text { Psychosocial } \\
\text { Measures }\end{array}$ \\
\hline & & & & $\begin{array}{l}\text { b) Author's own "7 } \\
\text { point approach" }\end{array}$ \\
\hline $\begin{array}{l}\text { Fava et al. [7] } \\
\quad 1980\end{array}$ & 20 & Inpatients & $\begin{array}{l}20 \text { inpatients with } \\
\text { chronic uticaria } \\
20 \text { inpatients with } \\
\text { fungal infections }\end{array}$ & $\begin{array}{l}\text { a) Paykel's life events } \\
\text { questionnaire used } \\
\text { in semistructed } \\
\text { interview } \\
\text { b) Kellner-Sheffield } \\
\text { Symptom Rating } \\
\text { Test (SRT) } \\
\text { c) Schalling-Sifneos } \\
\text { Personality Scale } \\
\text { for Alexithymia }\end{array}$ \\
\hline
\end{tabular}

$16 \%$ cases psoriasis "conflictogenic"

$5 \%$ cases psoriasis "conflictogenic, preceded by stress"

$7 \%$ no conslusion.

a) $80 \%$ psoriatics, $90 \%$ patients with chronic urticaria vs. $50 \%$ patients with fungal infections reported at least 1 life event 6 months prior to onset of symptoms

b) Patients with psoriasis and urticaria had higher anxiety, depression and inadequacy scores than patients with fungal infections

c) No significant difference between groups in alexithymia ratings.

$\begin{array}{cccc}\begin{array}{c}\text { Matussek et } \\ \text { al. [16] 1985 }\end{array} & 38 & \begin{array}{c}\text { Inpatients and } \\ \text { outpatients }\end{array} & \begin{array}{l}113 \text { depressives } \\ 32 \text { healthy controls }\end{array}\end{array}$

Questionnaire for Measuring Factors of Aggression (FAF) (Hampel, 1975)
Psoriatics demonstrated "highest spontaneous aggression", "marked aggression toward others" and "low autoaggression."

\begin{tabular}{|c|c|c|c|c|c|}
\hline $\begin{array}{l}\text { Arnetz et al. } \\
\text { [17] } 1985\end{array}$ & 10 & $\begin{array}{l}\text { Patients who re- } \\
\text { ported that their } \\
\text { psoriasis was } \\
\text { aggravated by } \\
\text { psychosocial } \\
\text { factors }\end{array}$ & 10 healthy subjects & $\begin{array}{l}\text { Psychological stress } \\
\text { induced by a) } \\
\text { color-word conflict } \\
\text { test and b) forced } \\
\text { mental arithmetic }\end{array}$ & $\begin{array}{l}\text { During stressor expo- } \\
\text { sure, psoriatics re- } \\
\text { ported a) } \\
\text { significantly higher } \\
\text { levels of stress and } \\
\text { b) excreted more } \\
\text { urinary adrenalin } \\
\text { than controls. }\end{array}$ \\
\hline $\begin{array}{l}\text { Payne et al. } \\
\text { [18] } 1985\end{array}$ & 16 & $\begin{array}{l}\text { Outpatients with } \\
\text { psoriasis who } \\
\text { completed a ret- } \\
\text { rospective postal } \\
\text { questionnaire }\end{array}$ & $\begin{array}{l}16 \text { patients with cu- } \\
\text { taneous neo- } \\
\text { plasms, warts, } \\
\text { fungal infection }\end{array}$ & $\begin{array}{l}\text { Life Events Inventory } \\
\text { [19] }\end{array}$ & $\begin{array}{l}\text { No significant differ- } \\
\text { ence in the number } \\
\text { of life events dur- } \\
\text { ing the previous } 2 \\
\text { years between } 2 \\
\text { groups }\end{array}$ \\
\hline
\end{tabular}


chopathology, 3) psychosocial problems associated with adaptation to a chronic and cosmetically disfiguring disease, and 4) biochemical and physiologic abnormalities in psoriasis that interface with psychiatry. In our experience at the Psychodermatology Clinic, all these four areas must be taken into consideration in the psychiatric evaluation and management of patients with psoriasis. This article also provides the clinician with some practical guidelines for the management of some of these problems.

\section{Psychosocial "Stress" and Psoriasis}

There is a relatively large body of literature implicating stressful life situations in precipitating and/ or exacerbating psoriasis $[2-7,11,15,17,20,22-27]$. However, the nature of this association remains unclear. In a survey of over 4500 dermatologic patients, $2 \%$ of the patients had psoriasis, and emotional factors were reported to "trigger the onset of symptoms" in $62 \%$ of the psoriatics [24]. In a Danish study involving 245 children with psoriasis, "stress" was observed to be a provocative factor in $90 \%$ of patients [27]. Ingram [23] observed that psychosocial stressors exerted "the most potent influence" on psoriasis, whereas Baughman et al. [11] report that the effect of "stress" was "modest but significant." Both these conclusions are based upon uncontrolled observations. The studies using controls $[5,7]$ report that psychosocial factors were important in the onset and/or exacerbation of symptoms in 39\% [5] to $80 \%$ [7] of psoriatics versus $10 \%$ [5] to 50\% [7] of controls, respectively. The controls consisted of patients with a range of nondermatologic disorders [5] and patients with fungal infections of the skin [7]. On the other hand, based upon the results of a postal survey, Payne et al. [18] observed no difference in the number of life events between psoriatics and other dermatologic controls, concluding that "stress" did not play an important role in psoriasis. They asked their patients to note any events that occurred 12 months prior to the onset of psoriasis on a life events checklist adapted from the Life Events Inventory [19] without ascertaining the degree of "stress" associated with the event. In the studies where a significant relationship has been noted between the onset or exacerbation of psoriasis and life events, the subjects had been asked whether they had experienced "specific stress" 1 month before the onset of psoriasis [5], or whether they had a "stressful" life event 6 months prior to the onset of psoriasis in a semistructured interview [7]. It appears that the important factor is the psychologic distress or "stress" experienced by the patient rather than the life events per se. This is supported by a previous observation that the onset of psoriasis was clearly associated with a stressful life event only when the event was of "an acute catastrophic nature," for example, sudden death of a relative [4]. In such a case it is reasonable to assume that most people would experience significant psychologic distress. Furthermore, in a recent study, Arnetz et al. [17] have demonstrated that psoriatics experienced "significantly higher strain levels" in comparison with healthy controls, when both were exposed to the same stress provoking situation. This was measured by scores on standard questionnaires and increased urinary adrenalin levels [17]. It is also interesting to note that psoriatics who reported "specific stress" 1 month before the onset of psoriasis [5] were also observed to have better prognosis three years later [28]. It is possible that a subgroup of psoriatics who are "stress reactors" experience a relatively benign clinical course, as their symptoms subside after the stress-provoking situation becomes less bothersome or subsides. Identification of such patients early in the course of treatment and incorporation of specific psychosocial interventions in the overall treatment regimen may improve the course of illness. Although the concept of "stress" is difficult to operationalize, treatments such as supportive psychotherapy and facilitation of grieving may prove to be important clinical interventions in some patients. It has been observed that children with psoriasis "react more easily to physical and psychological trauma than do adults with psoriasis" [27]. The authors recommend that treatment of children with psoriasis should involve a close parent-child-physician relationship and preferably be carried out in an outpatient setting to minimize the stress of hospitalization [27]. It is possible that in some children with psoriasis who have family pathology, a family assessment and family therapy may improve the course of illness.

\section{The Association of Psoriasis and Psychopathology}

Many investigators have attempted to delineate specific personality characteristics in psoriasis using questionnaires $[4,6,7,10,11,13,16,29,30]$ and 
clinical interviews [3]. This is a follow-up on the classic work of French and Alexander [31], who described neurodermatitis as one of the "holy seven" psychosomatic disorders, and the pioneering work of psychoanalytically oriented psychiatrists like Wittkower [32], who looked for relationships between personality structure, emotional conflict, and skin disease [32]. Although most have concluded that psoriatics do not have any characteristic personality traits $[3,4,6,11,13]$, some have reported high measures of outward aggression [16], high depression [7,30], high anxiety [7], and high obsessionality [29] and psychasthenia [10] scores on various psychologic questionaires (Table 1). The clinical relevance of these findings is difficult to evaluate, as all the studies have involved a one-time cross-sectional evaluation of personality characteristics $[3,4,6,7,10,11,13,16,29,30]$. In one study where the ages of the patients ranged between 15 and 83 years and duration of psoriasis ranged between 5 and 40 years [10], the relation between duration of symptoms and personality characteristics was evaluated, and no consistent patterns emerged. Although some of the abnormal psychologic characteristics reported are most likely a reflection of the reaction to adaptation to a chronic cosmetically disfiguring illness, in some instances onset of psoriasis during developmentally critical periods may also affect the psychological growth of the individual [33]. To our knowledge, evaluations of psychiatric syndromes among psoriatics, employing standard diagnostic criteria, for example DSM-III, have not been reported.

Chaput et al. [34] have reported a higher prevalence of psoriasis among individuals who consumed more than $50 \mathrm{~g}$ of ethanol per day. Morse et al. [9] have recently reported an $18 \%$ prevalence of alcoholism among psoriatics versus a $2 \%$ prevalence among other dermatologic controls, using the criteria of the National Council for Alcoholism and the Self-Administered Alcohol Screening Test. They also found no relationship between alcoholism and the duration of psoriasis, suggesting perhaps that having psoriasis alone predisposes the patient to developing alcoholism. Previous reports, using less stringent diagnostic criteria for alcoholism [35-37] have refuted the association between alcoholism and psoriasis. Alcoholism among psoriatics may, for example, represent an underlying depressive illness, or may represent an attempt at self-medication for, e.g., anxiety, social phobias, or sleep difficulties. This has important treatment implications and requires further evaluation.

\section{Psychosocial Problems Encountered as a Result of Psoriasis}

\section{Body Image}

Disfigurement occurring during adolescence has been reported to have a great impact on body image in later life $[38,39]$. This may be especially important in psoriasis, where $58 \%$ of patients develop psoriasis before age 30 years, 35\% before age 20 years, and $10 \%$ before age 10 years [40]. Presence of lesions on exposed body parts [41] and increased severity [42] have both been reported to adversely affect the patient's body image.

\section{Sexual Functioning}

Psoriasis has been reported to effect the sexual functioning of the patient in $72 \%$ of cases [43]. When psoriasis is present in the more "emotionally charged" areas of the body, such as the genital area, sexual functioning is more affected [44]. Trauma to the genitals following sexual activity can result in new psoriatic lesions or an exacerbation of previous lesions as a result of the Koebner phenomenon, a feature of psoriasis where new psoriatic lesions have a tendency to appear at sites of trauma [45]. The fear of passing on psoriasis to the offspring, and myths about the possibility of contagion may also lead to significant sexual problems [3]. Marriage may be deferred [32,33] as a result of these concerns.

\section{Others}

Psoriasis has been associated with contagion, filth, and leprosy for centuries $[43,44]$. Wittkower and Russell [32] observed that psoriasis was often attributed to "venereal disease, dirt, and neglect," leading to a "considerable social effect." Presence of psoriasis in areas of high visibility such as face and hands can impair social and occupational functioning to a significant degree $[3,32,33,43,44]$. The patient may be discriminated against in public places such as beaches and hotels and in hairdressing salons. They frequently give up swimming, sunbathing, and activities that necessitate exposure of their skin to others $[3,46]$. Light-colored clothing may be chosen to cover the affected regions of the skin and camouflage the scales that 
are shed $[3,33,46]$. Patients may develop a pervasive preoccupation with the anticipated negative response of others and, while dealing with these day-to-day problems, may experience a sense of "losing control" when faced with an unexpected exacerbation of their illness [33]. A poignant description of this has been given by Updike $[47,48]$.

Medical treatments for psoriasis in day care centers versus inpatient hospitalization, for example, may interfere less with the daily functioning of the patient [49]. Education of the public, regulations ensuring that patients with psoriasis are not discriminated against in public facilities such as beaches and hotels $[49,50]$, and group therapy aimed at dealing with the personal and social problems associated with psoriasis $[33,51,52]$ are all important. The preliminary results of a recent large scale self-report survey, carried out by the National Psoriasis Foundation [53] reports that psoriasis did not significantly interfere with patients' social relationships. It is possible that this reflects an increasing awareness among the general population about the myth regarding psoriasis.

\section{Physiological and Biochemical Correlates of Psoriasis that Interface with Psychiatry}

\section{Lithium and Psoriasis}

Lithium may precipitate and frequently exacerbate psoriasis [54,55]. This effect is believed to be mediated by the effect of lithium on the two intracellular "second messenger" systems, cyclic adenosine monophosphate (cAMP) and the phosphoinositides.

Lithium has an inhibitory effect on adenylate cyclase, leading to decreased levels of cAMP $[56,57]$. Psoriasis has been associated with decreased responsiveness of the $\beta$-adrenergic receptors in the epidermal cells [58]. These $\beta$-adrenergic receptors are linked with the adenylate cyclasecAMP system. Further inhibition of adenylate cyclase by lithium therefore can exacerbate psoriasis. Lithium also effects the phosphoinositide pathway by inhibiting the enzyme inositol monophosphatase, thus slowing the rate of resynthesis of phosphatidylinositol [59]. In psoriasis abnormalities have been found in the arachidonic acid transformation cascade [60]. This can be further exacerbated by the effect of lithium on the phosphoinositide pathway. An in-depth discus- sion of the biochemical abnormalities in psoriasis is not within the scope of this article.

Major depressive disorder has been associated with reduction in lymphocytes $\beta$-adrenergic responsiveness, as measured by agonist-induced cAMP production [61]. The lymphocytes have been implicated as peripheral models of central $\beta$-adrenergic receptor function. This possible defect in $\beta$-adrenergic receptor function in both psoriasis and depressive illness, along with some reports of a possibly increased prevalence of depressive symptoms $[7,33]$ and alcoholism $[9,34]$ among psoriatics, suggests that the association between psoriasis and affective disorders requires further investigation.

\section{Neuropeptides and Psoriasis}

Farber et al. [62] have proposed that substance P, a neuropeptide involved in itch and pain perception and the modulation of inflammation, may be involved in psoriasis, especially in cases where the lesions follow a symmetric dermatomal distribution. Substance $P$ has been demonstrated in intraepidermal nerve endings and there have been reports of resolution of psoriasis with cutaneous nerve resection [63]. The authors further discuss that since the epidermis and the nervous system are developmentally both derived from the embryologic ectoderm, neural factors may affect epidermal cells [62].

\section{Cutaneous Blood Flow}

Psoriasis has been associated with increased cutaneous blood flow [64-66], and improvement in psoriasis has been associated with a decrease in the cutaneous blood flow [66-68]. This may be due to the change in morphology of the capillaries of psoriatic skin [64]. More than three decades ago Graham [69] had observed that cutaneous blood flow, as measured by skin temperature and the reactive hyperemia threshold, increased significantly in the patient with psoriasis when the topic of discussion involved a disturbing life situation. In accordance with the most popular theories then in vogue, this was attributed to an "attitude" that these patients might have had in common [69].

Several studies $[70,71]$ have reported that temperature biofeedback training was associated with a significant decrease in the severity of psoriasis. The efficacy of this method appears to be related 
to the more generalized relaxation response initiated by the biofeedback [70,71], rather than decreased cutaneous blood flow. The role of psychophysiologic factors affecting cutaneous blood flow, in the exacerbation of psoriasis requires further evaluation.

\section{Some Practical Guidelines for Psychosocial Intervention in Psoriasis}

The psychiatrist is typically called upon a) to manage psychiatric pathology such as affective disorder in the psoriatic patient and b) for a psychopharmacologic consultation, when psoriasis is precipitated or exacerbated in a patient being maintained on lithium.

The patient must be evaluated within a developmental context, and the social, occupational, and close interpersonal functioning of the patient must be assessed, along with the psychiatric pathology including suicide risk. The assessment of the dayto-day difficulties faced by the patient is especially important, as in the subgroup of "stress reactors" having to cope with this may alone exacerbate the skin condition. Psychologic interventions aimed at helping the patient deal with these "stresses" may be helpful. Several studies report the efficacy of hypnosis-induced relaxation [72-74] and psychotherapy $[75,76]$ as a helpful adjunct in the treatment of psoriasis. In our experience, brief hospitalization aimed at removing the patient from a stressful environment may lead to significant improvement of psoriasis in some cases.

Potent topical steroids frequently used to treat psoriasis may be systemically absorbed and alter the mental state of the patient [30], and may depress adrenocortical function [77], thus affecting diagnostic procedures such as the dexamethasone suppression test.

Psoriasis precipitated or exacerbated by lithium is typically fairly resistant to conventional antipsoriatic treatment [78]. This may occur within the first few months of treatment and usually occurs within the first few years that the patient is on lithium $[79,80]$ Usually there is no family history of psoriasis [78]. When the psoriasis becomes widespread and intractible, lithium has to be discontinued [79] and the psoriasiform rash usually remits within a few months [78], or the rash reverts back to its premorbid state [78]. Having to discontinue lithium can typically pose a major management problem for the psychiatrist. For the bipolar patient discontinuing lithium, alternative treatments such as carbamazepine may be necessary, and the patient may need antipsychotic or antidepressant medications for stabilization of the mood disorder. The phenothiazine antipsychotics $[81,82]$ and some antidepressants [83-85] can cause a photosensitive skin rash when a patient is exposed to ultraviolet A (UVA) light. Since UVA with psoralens (PUVA) is frequently used as a treatment for psoriasis, this side effect may also interfere with the management of psoriasis. Management of patients whose mood disorder does not stabilize without lithium involves an ongoing evaluation of the risk-to-benefit ratio associated with reintroduction of lithium. In some cases, lithium may have to be restarted for a limited period at various times.

\section{References}

1. Farber EM, Van Scott EJ: Psoriasis. In Fitzpatrick TB, Eisen AZ, Wolff K, Freedberg IM, Austin KF (eds), Dermatology in General Medicine, 2nd ed. New York, McGraw-Hill, 1979, pp 233-252

2. Farber EM, Bright RD, Nall ML: Psoriasis, a questionnaire survey of 2144 patients. Arch Dermatol 98:248-259, 1968

3. Wittkower E: Psychological aspects of psoriasis. Lancet 1:566-569, 1946

4. Susskind W, McGuire RJ: The emotional factor in psoriasis. Scot Med J 4:503-507, 1959

5. Seville RH: Psoriasis and stress. Br J Dermatol 97:297-302, 1977

6. Gilbert AR, Rodgers DA, Roenigk HH Jr: Personality evaluation in psoriasis. Cleve Clin Q 40:147-152, 1973

7. Fava GA, Perini GI, Santonastaso P, Fornasa CV: Life events and psychosocial distress in dermatological disorders: Psoriasis, chronic urticaria and fungal infections. Br J Med Psychol 53:277-282, 1980

8. Sandborn DE III, Sandborn CJ, Cimbolic P, Niswander GD: Suicide and stress-related dermatoses. Dis Nerv Sys 33:391-394, 1972

9. Morse RM, Perry HO, Hurt RD: Alcoholism and psoriasis. Alcoholism 9:396-399, 1985

10. Goldsmith LA, Fisher M, Wacks J: Psychological characteristics of psoriatics. Arch Dermatol 100:674 676, 1969

11. Baughman R, Sobel R: Psoriasis, stress and strain. Arch Dermatol 103:599-605, 1971

12. Jobling RG: Psoriasis-A preliminary questionnaire study of suffers' subjective experience. Clin Exp Dermatol 1:233-236, 1976

13. Van der Schaar WW: Psychometric investigation in 48 Dutch patients suffering from psoriasis. Psychother Psychosom 27:159-162, 1976/77

14. Roenigk RK, Roenigk HH Jr: Sex differences in the psychological effects of psoriasis. Cutis 21:529-533, 1978 
15. Shanon J: Psoriasis: Psychosomatic aspects. Psychother Psychosom 31:218-222, 1979

16. Matussek P, Agerer D, Seibt G: Aggression in depressives and psoriatics. Psychother Psychosom 43:120-125, 1985

17. Arnetz BB, Fjellner B, Eneroth P, Kallner A: Stress and psoriasis: Psychoendocrine and metabolic reactions in psoriatic patients during standardized stressor exposure. Psychosom Med 47:528-541, 1985

18. Payne RA, Rowland Payne CME, Marks R: Stress does not worsen psoriasis?-A control study of 32 patients. Clin Exp Dermatol 10:239-245, 1985

19. Cochrane R, Robertson A: The life events inventory: A measure of the relative severity of psychosocial stressurs. J Psychosum Res 17:135-139, 1972

20. Medansky RS, Handler RM: Dermatopsychosomatics: Classifications, physiology, and therapeutic approaches. J Am Acad Dermatol 5:125-136, 1981

21. Engels WD: Skin disorders. In Kaplan HI, Sadock BJ (eds), Comprehensive Textbook of Psychiatry, 4th ed. Baltimore, Williams \& Wilkins, 1985, pp 11781185

22. Epstein KN, Baughman RD: Role of psychosomatic influences in psoriasis. In Epstein E (ed), Controversies in Dermatology. Philadelphia, Saunders, 1984, pp 200-203

23. Ingram JT: The significance and management of psoriasis. Br Med J 2:823-828, 1954

24. Griesemer RD, Nadelson T: Emotional aspects of cutaneous disease. In Fitzpatrick TB, Eisen AZ, Wolff K, Freedberg IM, Austen KF (eds), Dermatology in General Medicine, 2nd ed. New York, McGraw-Hill, 1979, pp 233-252

25. Baker H, Wilkinson DS: Psoriasis. In Rook A, Wilkinson DS, Ebling FJG (eds), Textbook of Dermatology, 3rd ed. Oxford, Blackwell, 1979, vol 2, pp 13151367

26. Koblenzer CS: Psychosomatic concepts on dermatology. Arch Dermatol 119:501-512, 1983

27. Nyfors A, Lemholt K: Psoriasis in children. Br J Dermatol 92:437-442, 1975

28. Seville RH: Psoriasis and stress. II. Br J Dermatol 98:151-153, 1978

29. Hardy GE, Cotterill JA: A study of depression and obsessionality in dysmorphophobic and psoriatic patients. Br J Psychiatry 140:19-22, 1982

30. Hughes JE, Barraclough BM, Hamblin LG, White JE: Psychiatric symptoms in dermatology patients. $\mathrm{Br} \mathrm{J}$ Psychiatry 143:51-54, 1983

31. Alexander F, French TM: Studies in psychosomatic medicine. New York, Ronald, 1948, pp 401-424

32. Wittkower E, Russell B: Emotional factors in skin disease. New York, Hoeber, 1953, pp 109-120

33. Dungey RK, Buselmeier TJ: Medical and psychosocial aspects of psoriasis. Health Soc Work 7:140-147, 1982

34. Chaput JC, Poynard T, Naveau S, Penso D, Durrmeyer $\mathrm{O}$, Suplisson D: Psoriasis, alcohol, and liver disease. Br Med J 291:25, 1985

35. Grunnet E: Alcohol consumption in psoriasis. Dermatologica 149:136-139, 1964

36. Parish LC, Fine E: Alcoholism and skin disease. Int J Dermatol 24:300-301, 1985
37. Delaney TJ, Leppard B: Alcohol intake and psoriasis. Acta Dermato-Venereol 54:237-238, 1974

38. Cash T, Winstead BA, Janda LH: The great American shape-up. Psychol Today 20:30-44, 1986

39. Berscheid E, Walster E, Bohrnstedt G: Body image, the happy American body: A survey report. Psychol Today 7:119-131, 1973

40. Farber EM, Nall ML: The natural history of psoriasis in 5600 patients. Dermatologica 148:1-18, 1974

41. Shuster S, Fisher GH, Harris E, Binnell D: The effect of skin disease on self-image. $\mathrm{Br} J$ Dermatol 99:1819, 1978

42. Leichtman SR, Burnett JW, Robinson HM Jr: Body image concerns of psoriasis patients as reflected in human figure drawings. J Person Assess 45:478-484, 1981

43. Weinstein MZ: Psychosocial perspective on psoriasis. Dermatol Clin 2:507-515, 1984

44. Buckwalter KC: The influence of skin disorders on sexual expression. Sex Disabil 5:98-106, 1982

45. Fiumara NJ: Psoriasis of the penis: Koebner reaction following oral genital exposure. J Am Vener Dis Assoc 3(2 part 1):59-60, 1976

46. Stankler L: The effect of psoriasis on the sufferer. Clin Exp Dermatol 6:303-306, 1981

47. Updike J: From the journal of a leper. New Yorker July 1976, pp 26-33

48. Updike J: Personal history: At war with my skin. New Yorker September, 1985, pp 39-57

49. Swanbeck G, Jobling R: Organization of psoriasis treatment and psychosocial aspects. Acta DermatoVenerol Suppl 112:61-63, 1983

50. Henley LA: Dealing with the disadvantaged-psoriasis. $\mathrm{Br}$ Med J 282:1851-1852, 1981

51. Coles RB, Ryan TJ: The psoriasis sufferer in the community. Br J Dermatol 93:111-113, 1975

52. Coles RB: Treatment of psoriasis in groups. Med World 103:127-135, 1965

53. Dermatology perspectives: 2, No. 2: 6, March-April 1986

54. Deandrea D, Walker L, Mehlmauer M, White K: Dermatological reactions to lithium: A critical review. J Clin Psychopharmacol 2:119-204, 1982

55. Sarantidis D, Waters D: A review and control study of cutaneous conditions associated with lithium carbonate. Br J Psychiatry 143:42-50, 1983

56. Digiovanna JJ, Aoyagi T, Taylor JR, Halprin KM: Inhibition of epidermal adenyl cyclase by lithium carbonate. J Invest Dermatol 76:259-263, 1961

57. Lazarus GS, Gilgor RS: Psoriasis, polymorphonuclear leukocytes, and lithium carbonate. Arch Dermatol 115:1183-1184, 1979

58. Voorhees JJ, Duell EA: Psoriasis as a possible defect of the adenyl cyclase-cyclic AMP cascade. Arch Dermatol 104:352-358, 1971

59. Berridge MJ: The molecular basis of communication within the cell. Sci Am 253:142-152, 1985

60 . Voorhees JJ: Leukotrienes and other lipoxygenase products in the pathogenesis and therapy of psoriasis and other dermatoses. Arch Dermatol 119:541547,1983

61. Mann JJ, Brown RP, Halper JP, Sweeney JA, Kocsis $\mathrm{JH}$, Stokes PE, Bilezikian JP: Reduced sensitivity of 
lymphocyte beta-adrenergic receptors in patients with endogenous depression and psychomotor agitation. N Engl J Med 313:715-720, 1985

62. Farber EM, Nickoloff BJ, Recht B, Fraki JE: Stress, symmetry, and psoriasis: Possible role of neuropeptides. J Am Acad Dermatol 14:305-311, 1986

63. Dewing SB: Remission of psoriasis associated with cutaneous nerve resection. Arch Dermatol 104:220221, 1971

64. Klemp P: Local regulation of cutaneous blood flow in psoriasis. J Invest Dermatol 83:421-425, 1984

65. Klemp P, Staberg B: Cutaneous blood flow in psoriasis. J Invest Dermatol 81:503-506, 1983

66. Staberg B, Klemp P: Skin blood flow in psoriasis during goeckerman or beech tar therapy. Acta Dermato-Venerol (Stockh) 64:331-364, 1984

67. Braverman IM, Sibley J: Role of the microcirculation in the treatment and pathogenesis of psoriasis. J Invest Dermatol 78:12-17, 1982

68. Klemp P: Regulation of local subcutaneous blood flow in patients with psoriasis and effects of antipsoriatic treatment on subcutaneous blood flow. J Invest Dermatol 85:175-178, 1985

69. Graham DT: Relation of psoriasis to attitude and to vascular reactions of the human skin. J Invest Dermatol 22:379-387, 1954

70. Benoit LJ, Harrell EH: Biofeedback and control of skin cell proliferation in psoriasis. Psychol Rep 46:831-839, 1980

71. Hughes HH, England R, Goldsmith DA: Biofeedback and psychotherapeutic treatment of psoriasis: A brief report. Psychol Rep 48:99-102, 1981

72. Frankel FH, Misch RC: Hypnosis in a case of longstanding psoriasis in a person with character problems. Int J Clin Exp Hypn 21:121-130, 1973

73. Waxman D: Behavior therapy of psoriasis-A hypnoanalytic and counter-conditioning technique. Postgrad Med J 49:591-595, 1973

74. Dengrove E: Emotional aspects of psoriasis. J Am Soc Psychosom Dent Med 23:126-132, 1976

75. Leuteritz G, Shimshoni R: Psychotherapy and psoriasis-Results at the dead sea. Z Hautkr 57:16121615,1982
76. Shafii M, Shafii SL: Exploratory psychotherapy in the treatment of psoriasis. Arch Gen Psychiatry 36:1242-1245, 1979

77. Aso M: The effects of potent topical corticosteroids on adrenocortical function. J Dermatol 10:145-149, 1983

78. Selmanowitz VJ: Lithium, leukocytes and lesions. In Fellner MJ, Zeide DA (eds), Clinics in Dermatology, Philadelphia, Lippincott, 1986, vol. 4, no. 1, pp 170175

79. Skoven I, Thormann J: Lithium compound treatment and psoriasis. Arch Dermatol 115:1185-1187, 1979

80. Carter TN: The relationship of lithium carbonate to psoriasis. Psychosomatics 13:325-327, 1972

81. Pavlidakey GP, Hashimoto K, Heller GL, Daneshver S: Chlorpromazine-induced lupus-like disease: Case report and review of the literature. J Am Acad Dermatol 13:109-115, 1985

82. Kahn G, Davis BP: In vitro studies on long-wave ultraviolet light-dependent reactions of the skin photosensitizer chlorpromazine with nucleic acids, purines and pyramidines. J Invest Dermatol 55:47-52, 1970

83. Kochevar IE: Possible mechanisms of toxicity due to photochemical products of protriptyline. Toxicol Appl Pharmacol 54:258-264, 1980

84. Hare PJ: "Visage mauve" (? from imipramine). Br J Dermatol 83:420-423, 1970

85. Schoonover SC: Depression. In Bassuk EL, Schoonover SC, Gellenberg AJ (eds), The Practitioner's Guide to Psychoactive Drugs. New York, Plenum, 1983, pp 19-74

Direct reprint requests to:

M.A. Gupta, M.D.

Department of Psychiatry

University of Michigan Hospitals

1500 E. Medical Center Drive

Box 0704

Ann Arbor, MI 48109-0704 